\title{
The introduction of modern forest management and clear-cutting in Sweden: Ridö State Forest 1832-2014
}

\author{
Hanna Lundmark ${ }^{1}$ (1) $\cdot$ Torbjörn Josefsson $^{1} \cdot$ Lars Östlund $^{1}$
}

Received: 21 July 2016/Revised: 13 January 2017/ Accepted: 18 January 2017/Published online: 9 February 2017

(C) The Author(s) 2017. This article is published with open access at Springerlink.com

\begin{abstract}
The effects of clear-cutting and potential alternatives continue to be hot topics during discussions of forestry and nature conservation. This study presents forest data from Ridön, an island in Lake Mälaren in central Sweden, where forest management and clear-cutting have been applied for almost 200 years. The main objective of the study was to identify changes in forest management and forest conditions over time. The forest transition in Sweden during the 1800s is also covered, and the importance of early forest experiments is discussed, exemplified by Ridön. This study is based on eight forest management plans and maps, from 1832 to 2014. Our results show a transformation from large, continuous areas of heterogeneous forest to small homogeneous stands. Clear-cutting has been the main logging method applied to Ridön for almost 200 years, which is in contrast with the general historical trend of selective cutting preceding clear-cutting in the Nordic countries. Our analysis shows that forestry has changed from the exploitation of resources to sustainable management. Currently, forest management at Ridön aims to create a nature reserve characterized by unevenaged forest with an increased deciduous component. Hence, the intention is to obtain a forest similar to as it was in 1832. By analyzing spatially precise data on forest stands over long periods and in relation to contemporary silvicultural methods, it is possible to discern the impact of forest management, to understand the drivers of the long-
\end{abstract}

Communicated by Aaron R Weiskittel.

Hanna Lundmark

hanna.lundmark@slu.se

1 Department of Forest Ecology and Management, Swedish University of Agricultural Sciences, 90183 Umeå, Sweden term changes in managed forest, and it also allows for a more educated discussion on today's forest management.

Keywords Forest history $\cdot$ Historical records $\cdot$ Selective cutting - Nature conservation - Sustainable forest management

\section{Introduction}

The early nineteenth century was a turning point for forest management in Sweden, characterized by the emergence of general interest in the forest as a sustainable resource. The foundations for organized forestry (defined as operations where forest is utilized for timber production and subsequent processing and use) were laid during this period and in 1828 a State Forest Institute (Sw.: Skogsinstitutet), the first advanced forestry school in Sweden, was founded (Wahlgren 1928). One of the reasons underlying the introduction of forest management (defined as the longterm administrative, economic, legal and social aspects of forestry, with aspects to silviculture, protection and forest regulation) at this time was the quantitative expansion of the ironworks, which required large amounts of wood (Wieslander 1936; Arpi 1951). Another reason was a growing concern for limited forest resources (Wieslander 1936; Eliasson 2002), a concern that had spread to Sweden from other European countries that had experienced forest deficiency and severe deforestation (Williams 2006; Kaplan et al. 2009). Those advocating the introduction of forest management requested the model of controlled and organized forestry that had already been introduced in Germany (Wahlgren 1917). This German model was easy to understand and implement because it included simple guidelines for the classification and assessment of forests, 
along with general rules for management and logging (Knuchel 1953; Noble and Dirzo 1997). These ideas quickly spread to areas outside of Germany. In Denmark, organized forestry was first introduced in the 1760s (Mather et al. 1998), and by the early nineteenth century, forest management plans had been developed for many forest estates (Serup 2005). In Switzerland, the influences from Germany resulted in clear-cutting (defined as commercial cutting of all trees in a certain area) and artificial regeneration during the nineteenth and twentieth centuries (Bürgi and Schuler 2003).

When organized forest management was introduced in Sweden during the nineteenth century, the state of the forests in different parts of the country varied greatly. In some parts of southern Sweden, especially in the westernmost parts, slash-and-burn cultivation, exploitation of broadleaved forest and grazing significantly reduced the extent of the forest until the mid-1800s, while the heathland was spreading (Malmström 1939; Östlund 1999). In central Sweden, forests had been used for charcoal production and iron works since the sixteenth century (sometimes even earlier), and the forest resources were decreasing, but not as rapidly as in southern Sweden (Brynte 2002). In northern Sweden, commercial logging was of minor importance until the mid-1800s, when an increased demand from the industrial parts of Europe initiated large-scale logging of large Scots pine (Pinus sylvestris L.) trees (Björklund 1984; Östlund et al. 1997). A significant amount of research has analyzed the development of forest management in Sweden during the late 1800 s and early 1900 s, i.e., when forestry expanded dramatically in Sweden (Östlund et al. 1997; Aasetre and Bele 2009; Lundmark et al. 2013). However, far less is known about how forestry was first implemented in Sweden. Apparently, forest management in the nineteenth century was promoted through two major pathways. Some of the large estates in southern Sweden employed Danish or German foresters to implement organized forestry (Brunet 2005), which included long-term management plans that would maintain sustainable yields (Ström 1822; Eliasson 2002). In central Sweden, on the other hand, new ideas were introduced by Swedish forestry protagonists who had visited the countries where forest management had been developed and/or implemented (Brynte 2002; Brunet 2005). Israel Adolf af Ström, who had gone to Germany and Denmark on study trips during the early 1800 s, was the foremost of these protagonists. In 1830, he drafted the first management plan for a specific forest in Sweden, Kungliga Djurgårdens förvaltning, and advocated clear-cutting as the preferred logging method (Wahlgren 1928). Two years later, in 1832, a management plan for the Ridö State Forest in central Sweden was implemented.
Currently, only limited knowledge about how this early Swedish forest management was implemented and which logging methods were used exists. Historical knowledge of previous forest management is important since it tells something about how different silvicultural practices have affected the forest structure. In turn, this knowledge can give indications about how we should manage our forests today and in the future. Studying previous forest management and learning about the differences in implementation between different areas can also contribute to a deeper understanding why the development and current situation differ between countries, despite a similar history. For example, the time and procedure for the introduction of modern forestry differs slightly between the Nordic countries. Forest management was introduced in Denmark during the mid-1700s (Mather et al. 1998), but was not systematized until the beginning of the 1800s (Serup 2004). Danish forest management followed the German model until the end of the nineteenth century (Serup 2004). Modern, scientific forest management was also introduced in Finland at about the same time as in Sweden and Denmark (Michelsen 1999). It was also based on the German tradition, but the Finnish foresters stressed that forest management should be adapted to a country's specific conditions rather than according to the models developed in other countries (von Berg 1859). Nevertheless, based on a description of the applied directives, the Finnish principles of forest management seemed to closely follow those applied in Germany, Denmark and Sweden (Michelsen 1999), and since 2014 the Finnish forest legislation also allows other alternatives than even-aged forest management (Rämö and Tahvonen 2014). Norway also has a long history of forestry but it was not until around 1900 that a more sustainable forest management was introduced (Aasetre and Bele 2009). Studies of specific areas are of great importance when comparing the Nordic as well as the European countries. Analysis on stand level contributes with detailed knowledge about the foresters' choice of forest management method, the driving forces behind these choices as well as the relationship between forest management methods and forest structure-knowledge that cannot be seen in broader studies of past forest management. Furthermore, analysis of detailed primary records also shows what was carried out in the forest and not only what was desired. Modern forest management, i.e., from the eighteenth century and onwards, has to a large extent been driven by ideas and ideals and therefore conflicts and clashes between different groups has been legio (cf. Hölzl 2010).

Internationally, several methods have been used to decipher the history of forestry and forest management (Whitney 1994), for example, dendrochronological stand analysis, aerial photoanalysis and analysis of series of 
forest management plans. The latter method is particularly robust since it covers a long period and can be used at different spatial levels. Detailed and consecutive historical records have been used to study the history of forest use and management in Switzerland during the nineteenth and twentieth centuries (Bürgi 1999), how modern forest management transformed a beech-dominated forest landscape in Sweden from 1840 to 2010 (Brunet et al. 2012), changes in tree species composition in private and state forests in Denmark from 1800 to 1950 (Serup 2005), logging history of a boreal forest in eastern Canada from 1840 to 2005 (Boucher et al. 2014), and the introduction of large-scale logging and overall forest transformation in a boreal forest landscape in Sweden (Östlund et al. 1997). In this study, we present data from Ridön, an island located in Lake Mälaren in the county of Södermanland, central Sweden. The Ridö State Forest has an unusually long record of management plans, and in this study, we used eight forest management plans and maps, the earliest from 1832 and the most recent from 2014, to analyze the early introduction and implementation of modern forest management in Sweden. Our aim was to analyze changes in forest conditions in the study area as a whole and at a local scale, using four stands with different management schemes (two were clear-cut and two were selectively cut) (selective cutting defined as commercial cutting of all trees with regards to dimension, quality or species). The research was guided by two questions. First, what silvicultural practices were planned and implemented? Additionally, how did the forest structure (age, species and standing volume) change over time (1832-2014) and how are these changes related to the applied silvicultural practices? Finally, with Ridön as an example, we discuss the nineteenth century forest transition (defined as the shift from net deforestation to net reforestation) in Sweden and the importance of experimentation during early forestry.

\section{Materials and methods}

\section{Study area and history}

Ridö State Forest is located on an island $\left(59^{\circ} \mathrm{N}, 17^{\circ} \mathrm{E}\right)$ in the southeastern part of Lake Mälaren in central Sweden (Fig. 1). The State Forest is managed by the forest owner, the National Property Board of Sweden (Sw.: Statens Fastighetsverk), and consists of a main island with a few small islands and islets in the vicinity. This study will focus on the main island, which comprises approximately 400 ha, of which 348 ha is covered by forest land. The island is elongated on the east-west axis $(6000 \mathrm{~m}$ long and 500-1000 m wide) and has a gently undulating topography. The eastern part of the island rises evenly and gradually from the shores, whereas the western shores are steep with exposed rock in many places. The soil generally derives from glacial till (Table 1: KD F3A). Ridön is dominated by mixed coniferous forest with a large element of deciduous trees. The main conifer species are Norway spruce [Picea abies (L.) Karst] and Scots pine, and the main deciduous species are birches (Betula sp.), grey alder [Alnus incana (L.) Moench], pedunculate oak (Quercus robur L.) and aspen (Populus tremula L.).

Whereas the eastern and central parts of the island are covered by forest land, the western part comprises forest land and open agricultural land (Fig. 1). This area has two farms, which include several buildings, such as dwelling houses, barns and farm buildings. The southwest side of the island has the Ridö tavern and a hunting residence-the former dating back to the 1600 s. The waterways played an important role during that period, and the Ridö tavern was one of many inns that existed along the shorelines of Lake Mälaren. There is also a gunpowder house and a dwelling house (Sw.: kruthusvaktarbostad) on the southeast side of the island. The powder house was built as a storage for the gunpowder produced at Åkers styckebruk, which is situated on the mainland. The powder house was built on the island for safety reasons. Ridön was first mentioned in written documents in 1554, when the island was called "Långerydön". One of the earliest resources on the island was hay, which was plentiful in the meadows and delivered to the royal stables (Sw.: hovstalläng) in Stockholm by haymakers. The first inhabitants were probably meadow lookouts, and with time leasehold farms concentrating on farming and fishing were established on the island (Anon 2011). During the next two centuries, the island was mostly utilized by farmers and fishermen until the early 1800 s, when Ridön became interesting from a forest management perspective.

\section{Analysis of historical records}

The historical records used in this study were obtained from the Regional State Archives in Härnösand and Vadstena (Table 1). These records consist of forest management plans and forest maps that cover a period of ca 180 years (1832-2014). The management plans contain detailed information about, for example, tree species, standing volume, stand age and planned loggings, which together with the forest maps provide a unique overall picture of the early forest management. Management plans with attached forest maps from 1832, 1869, 1896, 1915, 1929, 1947 and 1957 were analyzed. The management plans are very detailed and expressive until 1915, whereas management plans from 1929 onwards are shorter, with less informative descriptions, but do include maps that are more detailed and descriptive. All of the plans, except for the one from 1929, contain detailed information about each 
Fig. 1 Location and topographic map of the study area Ridön situated in Lake Mälaren, central Sweden

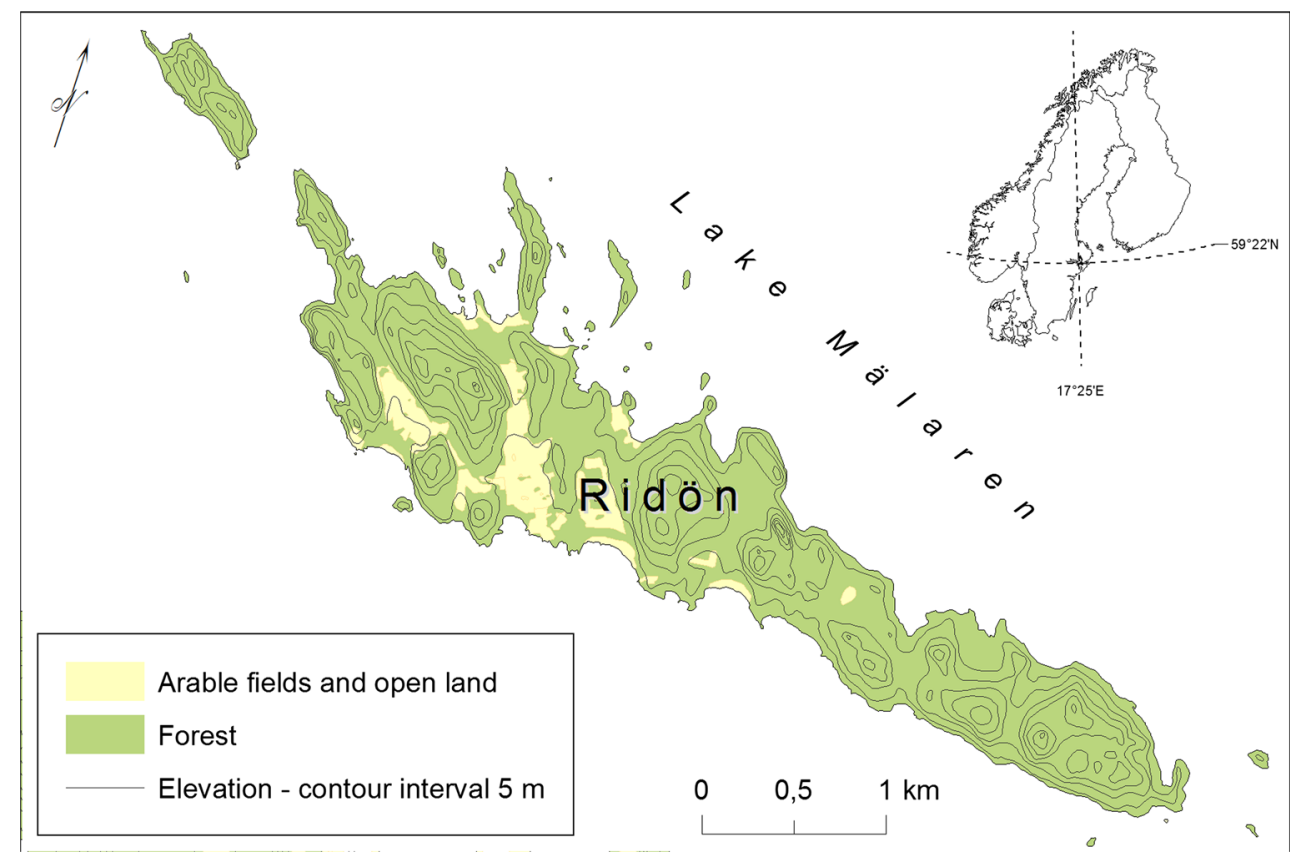

stand. Each management plan varies slightly from others. For this reason, the extracted data were categorized to enable comparisons between different years (Table 2). Forest data from 2014 were obtained from the National Property Board of Sweden.

Data concerning tree species composition, age and volume were extracted to analyze the overall changes in forest structure. Furthermore, four small areas within Ridö State Forest were closely examined to investigate the effects of different logging methods on forest structure. Two of these areas were clear-cut twice during the study period, and the other two were first selectively logged and only later clearcut once. The areas were identified by examining how the management plans were set up and implemented. An area was subjectively selected using the following criteria: (1) Only one of the logging methods was applied during the 1800s and (2) quantitative forest structure data could be extracted from all of the eight management plans. Other information that could be useful for understanding the forest management plans and maps were also gathered and analyzed. For example, the foresters thoughts and ideas concerning tree species and logging methods, who set up the plans and why, and regeneration issues.

\section{Results}

\section{Forest management}

In 1828, an investigation involving the state forester Israel af Ström concluded that forest management should be applied at Ridön (Table 1: KD F3A). According to the first forest management plan and forest map for the Ridö State Forest, established in 1832, the forest, which covered ca 270 ha, had been divided into 20 sub-units (using parallel lines in a north-south direction-Fig. 2a) that would be clear-cut. The management plan was divided into 24 consecutive 5 year periods, starting in 1832 and ending in 1952 (Table 3). The rotation period for regrowth, which was based on the ages of trees with saw timber qualities, soil quality and location, was set to 120 years. Every fifth year, an area of 11 ha would be clear-cut, and after 120 years, the entire forest would have been logged. The goal of this management scheme was to slowly and successively increase yields. This required proper forest management, good regeneration, and a new forest that is dense from the start. The plan also proposed the use of thinning to attain desired forest growth. Furthermore, the forest should be regenerated by natural regeneration and the plan set a number for the seed trees that should be left after logging, which could be logged once the new trees had become established. According to the management plan, healthy and growing trees should be selected as seed trees, and Scots pine should be selected whenever possible since they were considered more resistant to strong winds as a result of deeper roots than the Norway spruce. The plan was in use from 1832 until 1869, and during this time most of the forest on the eastern part of the island was clear-cut. The applied forest management followed the plan, and the mean annual yield was ca $490 \mathrm{~m}^{3}$ of timber (Table 1: KD F3A) (Tables 3, 4). 
Table 1 Unpublished sources used for data collection

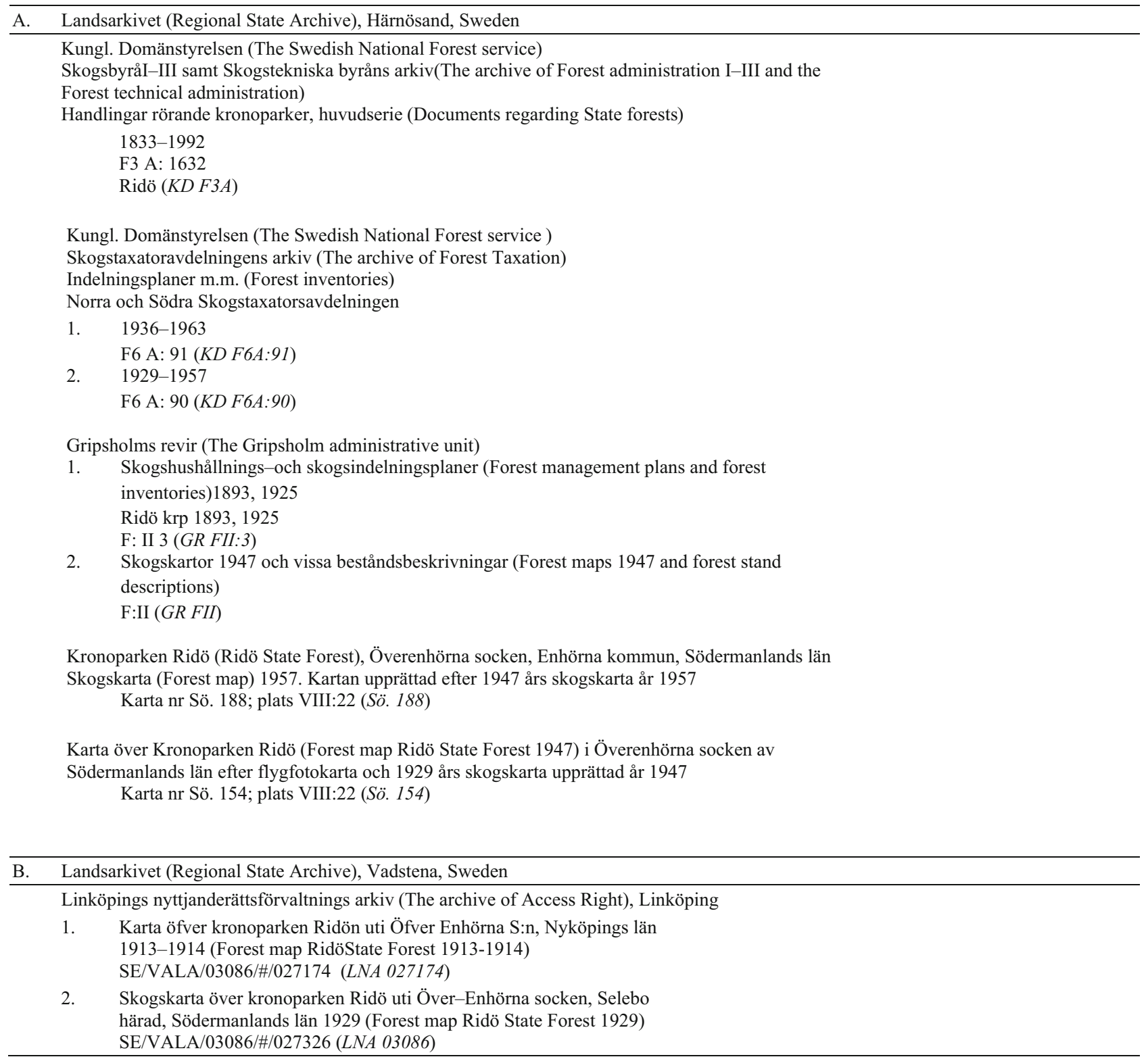

In 1869 , forestry students at the Royal Forest Institute (Sw.: Kungliga Skogsinstitutet) drafted a new management plan that used a similar system of sub-units as the previous plan (Fig. 2b). This new plan proposed the use of selective cutting (Sw.: ordnad blädning) rather than clear-cutting (Table 4). At that time, forest land covered ca 259 ha (Table 5), of which 59 ha were considered suitable for clear-cutting. However, as these stands were sparse, uneven-aged and included a large number of overstory trees, selective cutting was also to be applied to these stands. The plan was initially followed, but since the selective cutting resulted in forest stands that were easily damaged by storms, it was concluded that this logging method was not suitable for forests in an exposed area that had not been logged previously. As a result, clear-cutting was to be applied instead. In this plan, it was stated that the forest should be regenerated by natural regeneration and by planting Norway spruce, pedunculate oak, grey alder and European beech (Fagus sylvatica L.). This forest management plan was in use from 1869 to 1895 , and during this period, ca $720 \mathrm{~m}^{3}$ of wood were cut annually (Table 1: KD F3A) (Table 4).

A third management plan, which proposed the clearcutting of smaller areas, was introduced in 1896. 
Table 2 Age and species classifications according to Axelsson and Östlund (2001) used to reclassify forest data in management plans from 1832 , 1869, 1896, 1915, 1929, 1947, 1957 and 2014

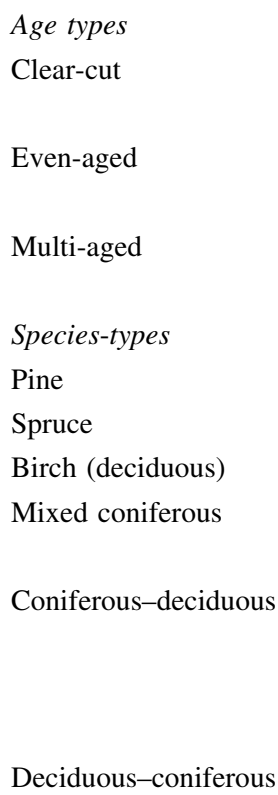

Deciduous-coniferous

According to this plan, the 20 sub-units were divided further into subdivisions with irregular shapes (Fig. 2c). The plan suggested that only healthy and growing trees would be logged, but since there were a lot of dry and wind-felled trees, a major part of the annual yield consisted of such trees. The forest should be regenerated by natural regeneration (Norway spruce, Scots pine and birch) and by planting (Norway spruce and Scots pine). About 60 ha forest land was planned for natural regeneration and about 15 ha for planting during this plan period. This management plan was in use until the end of 1914, and during this period an average of ca $520 \mathrm{~m}^{3}$ wood was logged annually, of which only $10 \%$ was considered as merchantable timber. Clear-cutting contributed to a minor portion of the annual yield and about $30 \mathrm{~m}^{3}$ came from thinning operations (Table 1: KD F3A) (Table 4).

A fourth plan, which used another form of selective cutting (Sw.: traktblädning or luckhuggning), was implemented in 1915. This plan was motivated by the poor regeneration rates in clear-cut areas. Furthermore, the plan entailed that neither selective cutting nor clear-cutting would be uniformly applied across the entire forest area. The forest map used in this management plan was based on the map from 1896 and included 20 sub-units with another subdivision that led to more individual stands (Fig. 2d). The management plan also stated that there was a surplus of old forest and a significant increase in logging volume would be necessary to fully harness the site productivity. The forest land was estimated to encompass 335 ha, and the annual yield was ca $1400 \mathrm{~m}^{3}$ (Tables 4,5$)$. During this period, besides planting of Norway spruce and Scots pine, there were some attempts to plant silver fir (Abies alba L.) to minimize the spreading of root rot. There were also natural regeneration of Norway spruce, Scots pine and birch. This management plan included instructions for how the forest should be managed during the next 20 years, but was only in use until 1929, when a fifth plan was introduced (Fig. 2e) (Table 1: LNA1, KD F3A).

The layout of forest management plans, as well as the maps they included, changed from 1929 onwards, and there are also differences in the division of the forest land (Fig. 2e-h). The parallel lines in north-south direction were still present in the 1929 map, but the sub-units in between these lines started to become more irregular in shape and smaller sub-units became more common. The management plans also became shorter with less informative descriptions. According to the fifth forest management plan from 1929, thinning should be applied to all stands, both young and old, that were considered suitable for thinning. The forest land area encompassed 389 ha at the time of this plan, and the annual yield was ca $1645 \mathrm{~m}^{3}$ (Tables 4, 5) (Table 1: LNA2, GR FII:3). This plan was in use from 1929 to 1946, and in 1947 a sixth plan came into use. The parallel north-south lines had disappeared from this plan (Fig. 2f), replaced with sub-units that had large variation in shape and size. The forest land was estimated to encompass 393 ha, but the annual yield was not specified (Table 1: KD F6A 90, 91, GR FII, Sö. 188). This plan was in effect for ten years, until 1957, when the next plan was introduced. The management plan and map from 1957 
Fig. 2 Forest maps of the easternmost part of Ridön Island: $\mathbf{a}-\mathbf{h}$ in $1832,1869,1896$, 1915, 1929, 1947, 1957 and 2014. Data obtained from the management plans for the Ridö State Forest (Table 1): A Kungl. Domänstyrelsen, and B

Linköpings

nyttjanderättsförvaltnings arkiv

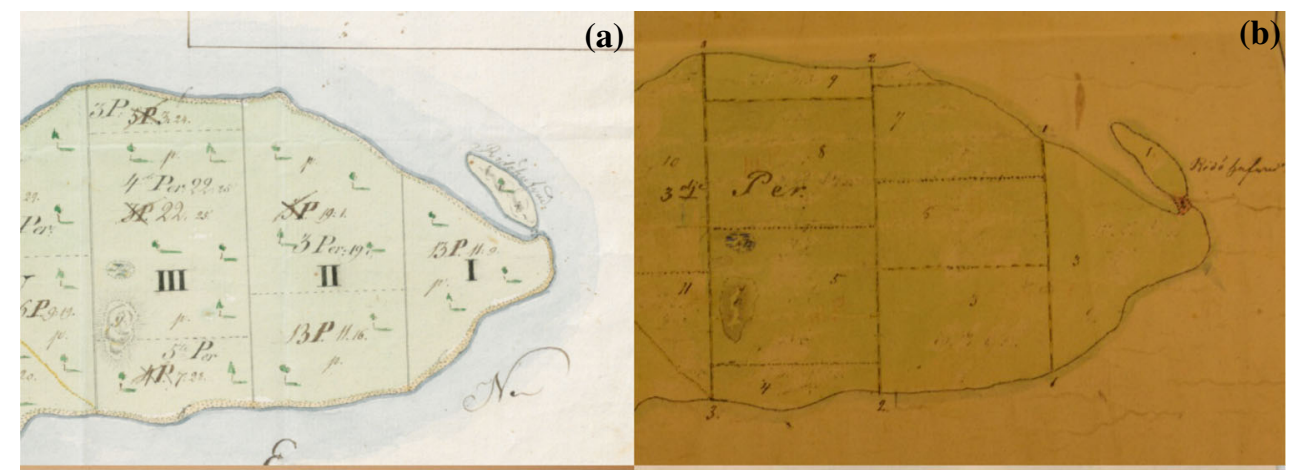

(c)
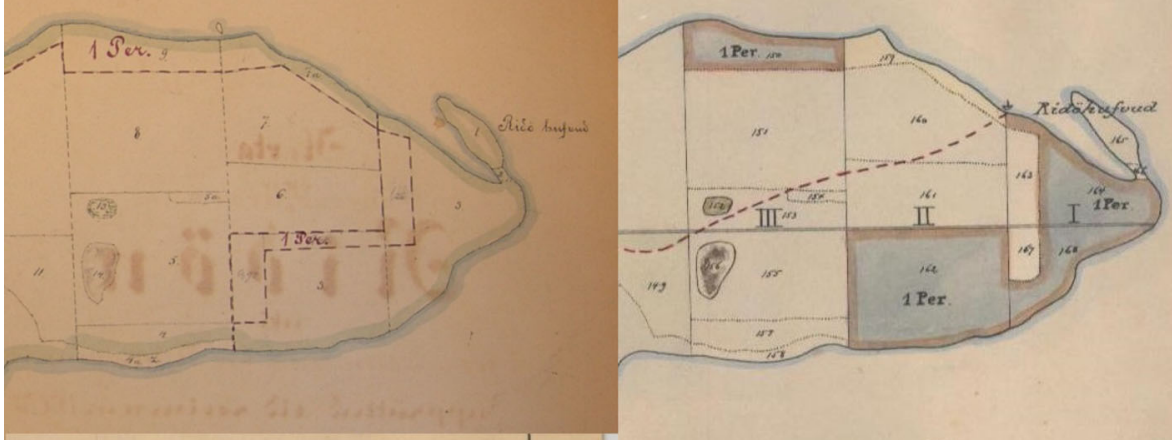

(e)

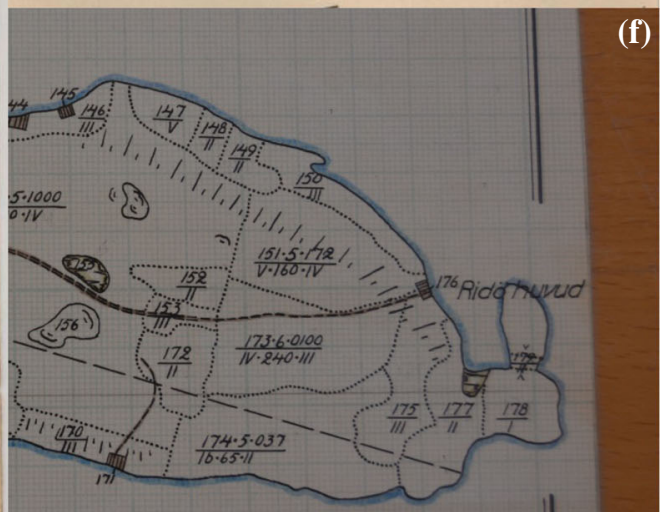

(g)

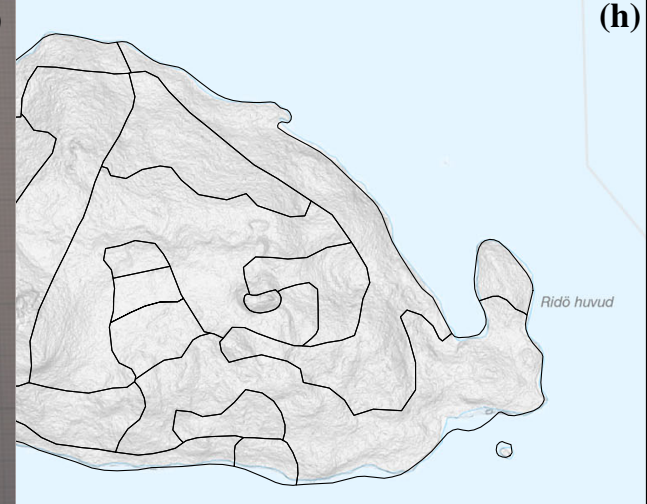

are similar to those from 1947 (Fig. 2g). The forest land area encompassed $412 \mathrm{ha}$, and the annual yield was ca $1715 \mathrm{~m}^{3}$. The plans and maps from 1947 and 1957 also indicate places for bird nests (osprey, Pandion haliaetus) (Table 1: KD F6A 90, 91, Sö. 154). According to the most recent plans, most of Ridön will become a nature reserve in the near future (Anon 2015). This management plan aims to increase the biodiversity by creating an uneven-aged forest and increasing the deciduous component in the forest. 
Table 3 Logging plan for forest to be clear-cut divided into 24 plan periods covering a total period of 120 years

\begin{tabular}{|c|c|c|c|c|}
\hline Plan period & Area (ha) & Volume/area $\left(\mathrm{m}^{3} \mathrm{ha}^{-1}\right)$ & Total volume $\left(\mathrm{m}^{3}\right)$ & Annual volume $\left(\mathrm{m}^{3}\right.$ year $\left.^{-1}\right)$ \\
\hline $1833-1837$ & 11 & 45 & 2451 & 490 \\
\hline $1837-1842$ & 11 & 45 & 2451 & 490 \\
\hline $1842-1847$ & 11 & 45 & 2451 & 490 \\
\hline $1847-1852$ & 11 & 45 & 2451 & 490 \\
\hline $1852-1857$ & 11 & 46 & 2484 & 502 \\
\hline $1857-1862$ & 11 & 46 & 2516 & 503 \\
\hline $1862-1867$ & 11 & 46 & 2516 & 503 \\
\hline $1867-1872$ & 11 & 46 & 2551 & 510 \\
\hline $1872-1877$ & 11 & 46 & 2551 & 510 \\
\hline $1877-1882$ & 11 & 46 & 2525 & 505 \\
\hline $1882-1887$ & 11 & 47 & 2549 & 512 \\
\hline 1887-1892 & 11 & 46 & 2553 & 511 \\
\hline 1892-1897 & 11 & 47 & 2580 & 516 \\
\hline 1897-1902 & 11 & 47 & 2580 & 516 \\
\hline 1902-1907 & 11 & 47 & 2600 & 520 \\
\hline 1907-1912 & 11 & 48 & 2613 & 525 \\
\hline 1912-1917 & 11 & 47 & 2584 & 517 \\
\hline 1917-1922 & 11 & 48 & 2658 & 532 \\
\hline $1922-1927$ & 11 & 53 & 2903 & 581 \\
\hline 1927-1932 & 11 & 52 & 2838 & 568 \\
\hline $1932-1937$ & 11 & 55 & 3012 & 602 \\
\hline 1937-1942 & 11 & 53 & 2903 & 581 \\
\hline 1942-1947 & 11 & 54 & 2967 & 593 \\
\hline 1947-1952 & 11 & 63 & 3473 & 695 \\
\hline
\end{tabular}

Data obtained from the 1832 management plan for the Ridö State Forest (Table 1): KDF3A

Table 4 Annually logged mean volumes $\left(\mathrm{m}^{3}\right)$ per hectare during the seven first management plan periods

\begin{tabular}{|c|c|c|c|c|c|c|c|}
\hline & \multicolumn{7}{|c|}{ Time periods } \\
\hline & $1832-1868$ & $1869-1895$ & 1896-1914 & 1915-1928 & 1929-1946 & $1947-1956$ & 1957-1966 \\
\hline Logging method $\left(\mathrm{m}^{3}\right)$ & & & & & $\mathrm{c}$ & $\mathrm{c}$ & $\mathrm{c}$ \\
\hline Clear-cutting & 491 & & 460 & & & & \\
\hline Selective cutting & & 592 & & 939 & & & \\
\hline Thinning & & 1 & 30 & 457 & & & \\
\hline Preparatory cutting $^{\mathrm{a}}$ & & 51 & 28 & & & & \\
\hline Cleaning cutting ${ }^{\mathrm{b}}$ & & 75 & 6 & & & & \\
\hline Mean volume in total/year & 491 & 719 & 524 & 1396 & 1645 & c & 1715 \\
\hline
\end{tabular}

From 1832 to 1928, the volumes are presented for each logging method and in total. Data obtained from the management plans for the Ridö State Forest (Table 1): A Kungl. Domänstyrelsen, and B Linköpings nyttjanderättsförvaltnings arkiv

${ }^{a}$ Logging of large overstory trees in order to increase light supply and prepare the stand for natural regeneration

${ }^{b}$ Logging of wind throws and snags

${ }^{\mathrm{c}}$ Not specified

\section{Forest structure}

In 1832, the Ridö State Forest consisted solely of mixed coniferous stands of Scots pine and Norway spruce, with a small amount of interspersed birch in some stands
(Fig. 3a). Other deciduous trees such as pedunculate oak, crab apple [Pyrus malus L. spp. sylvestris (L.) Hiitonen], rowan (Sorbus aucuparia L.), small-leaved lime (Tilia cordata Mill.), ash (Fraxinus excelsior L.), Norway maple (Acer platanoides L.) and bird cherry (Prunus padus L.) 
Table 5 Standing tree volumes and areal extent of different land-use categories for different years during the study period

\begin{tabular}{|c|c|c|c|c|c|c|c|c|}
\hline & \multicolumn{8}{|l|}{ Years } \\
\hline & 1832 & 1869 & 1896 & 1915 & 1929 & 1947 & 1957 & 2014 \\
\hline Standing tree volume $\left(\mathrm{m}^{3} \mathrm{ha}^{-1}\right)$ & 150 & 109 & 126 & 159 & 158 & 108 & 133 & 184 \\
\hline \multicolumn{9}{|l|}{ Area of land-use categories } \\
\hline Forest land (ha) & 270 & 259 & 284 & 335 & 389 & 393 & 412 & 348 \\
\hline Nonproductive forest land & 27 & 16 & 20 & 25 & 14 & 26 & 25 & 10 \\
\hline Total area (ha) & 297 & 275 & 304 & 360 & 403 & 419 & 437 & 358 \\
\hline Clear-cuts in $\%$ of forest land ${ }^{\mathrm{a}}$ & $0(0)$ & $17(44)$ & $5(14)$ & $8(27)$ & $6(22)$ & $3(11)$ & $7(30)$ & $6(22)$ \\
\hline
\end{tabular}

Data obtained from the management plans for the Ridö State Forest (Table 1): A Kungl. Domänstyrelsen, and B Linköpings nyttjanderättsförvaltnings arkiv

${ }^{\text {a }}$ Area of clear-cuts in hectares of forest land displayed within parentheses
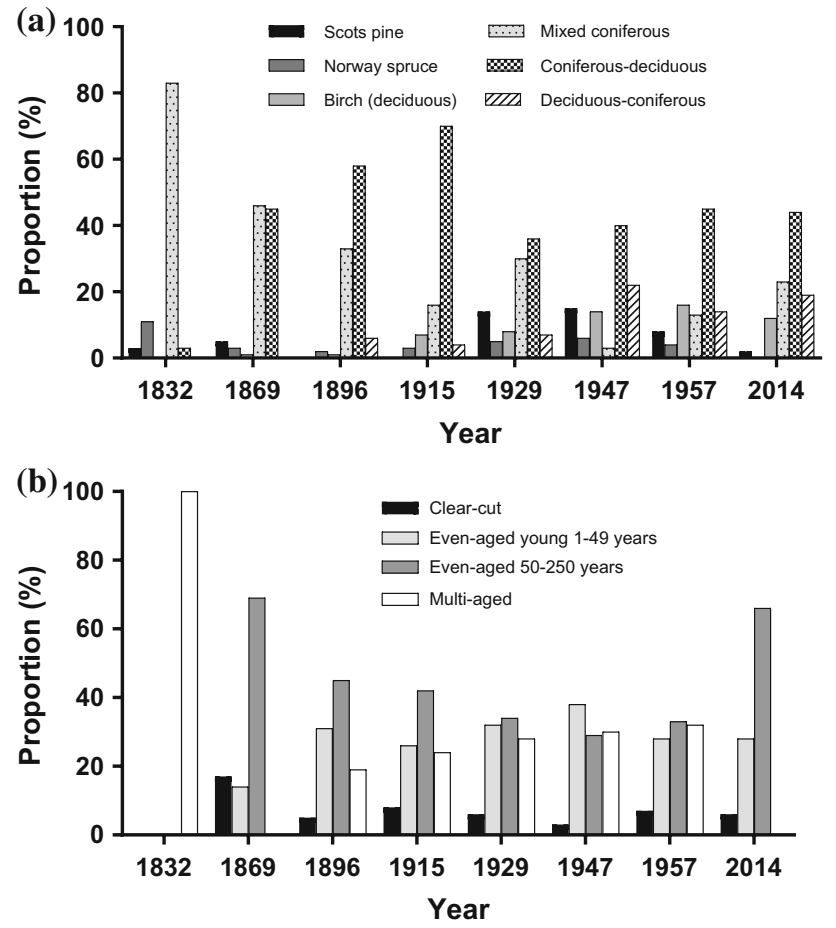

Fig. 3 Proportion of a total forested area of different forest types and b total forest land of different age types. Data obtained from the management plans for the Ridö State Forest (Table 1): A Kungl. Domänstyrelsen, and B Linköpings nyttjanderättsförvaltnings arkiv

were also present but only to a limited extent. In 1869 , the proportions of mixed coniferous and coniferous-deciduous stands were almost equal while the same ratio in 1896 was 33 and 58\%, respectively (Fig. 3a). In 1915, coniferousdeciduous forests made up $70 \%$ of the Ridö State Forest, which meant that the admixture of deciduous trees had increased, conifers were still the majority, and single-species stands of Norway spruce now covered only a small proportion of the forest land (Fig. 3a). When the fifth management plan (1929) was implemented, the proportion of mixed coniferous forest and coniferous-deciduous forest was about the same size, and single-species stands of Scots pine and Norway spruce covered ca 14 and 5\% of the forest area, respectively (Fig. 3a). In 1947 and 1957, deciduousconiferous forests (i.e., forests with a larger proportion of deciduous trees than conifers) covered 22 and $14 \%$ of the forest land, respectively, and single-species stands of Scots pine covered 15 and 8\%, respectively. In 2014, coniferousdeciduous stands covered the majority (44\%) of the forest followed by almost equal proportions of mixed coniferous and deciduous-coniferous stands, respectively, and a smaller proportion of birch/deciduous stands (Fig. 3a).

The forest land increased from 270 to 348 ha during the study period, peaking at 412 ha in 1957 . Between 1832 and 2014, the clear-cut areas varied from zero to 44 ha, reaching the largest areal extent in 1869. Initially (1832-1869), the standing volume decreased from 150 to $109 \mathrm{~m}^{3} \mathrm{ha}^{-1}$. However, by 1896 the standing volume had increased to $126 \mathrm{~m}^{3} \mathrm{ha}^{-1}$ and then stayed quite constant during the remainder of the study period, deviating only in $1947\left(108 \mathrm{~m}^{3} \mathrm{ha}^{-1}\right)$ and $2014\left(184 \mathrm{~m}^{3} \mathrm{ha}^{-1}\right)$.

When the first management plan was implemented in 1832, the entire Ridö State Forest was multi-aged (Fig. 3b). The management plan from 1869 did not mention multiaged stands. Instead, it described $69 \%$ of the forest land as even-aged, with an age range of 50-250 years (Fig. 3b). In 1869 , the forest land was also covered by clear-cuts (17\%) and young even-aged stands (14\%), and in 1915 clear-cuts covered only $8 \%$ of the forest land and young even-aged stands had increased, now covering $26 \%$ of the forest area. By the time, the fifth management plan (1929) came into effect, most of the forest land was covered by young(32\%) and old even-aged (34\%) stands, with multi-aged stands covering about a quarter of the area and the remaining $6 \%$ representing clear-cuts. The proportions between young even-aged forests, old even-aged forests, and multi-aged forests are almost equal in 1947 and 1957 (ca 30\%, respectively). In 2014, old even-aged stands dominated the forest at Ridön $(66 \%)$. The proportion of clear-cuts varies by 3-8\% between 1896 and 2014. From 


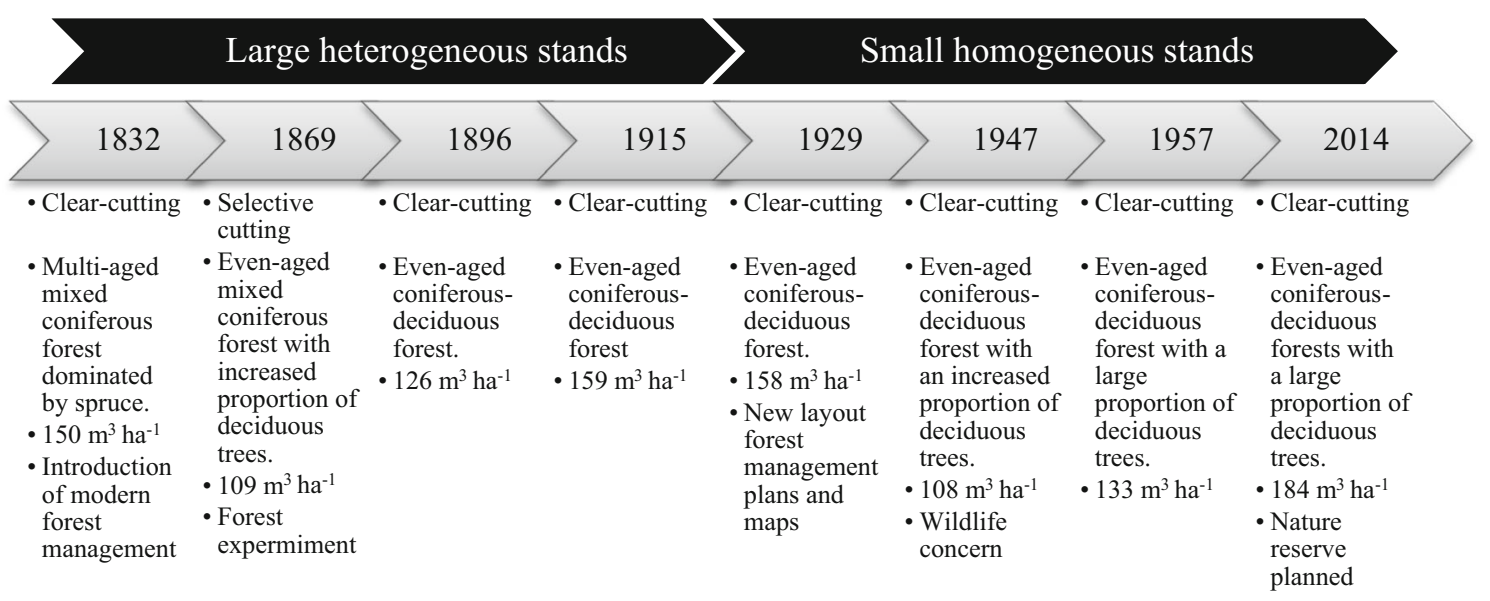

Fig. 4 Conceptual timeline with the main characteristics of each management plan specified (logging method, age and tree species composition, standing volume, other events)

1832-2014 the forest was converted from a large, continuous heterogeneous forest to small homogeneous stands (Fig. 4).

\section{Logging methods and local forest development}

The forest management applied and its effects on local forest development were analyzed in detail in four different areas: two forest stands where the earliest implemented logging was clear-cutting and two stands where the earliest implemented logging was selective cutting (Table 6). The sizes of the analyzed areas varied slightly between years because of changes in the division of sub-units under different management plans. Stand 1 (standing volume $191 \mathrm{~m}^{3} \mathrm{ha}^{-1}$ ) was chosen for clear-cutting during the period 1847-1952 and stand 2 (standing volume $201 \mathrm{~m}^{3} \mathrm{ha}^{-1}$ ) was to be clear-cut during the period 1842-1847. Accordingly, both stands are described as regenerated clear-cuts with zero standing volume in the management plan from 1869 (Table 6). Thinning was planned for stands 1 and 2 in the plans from both 1896 and 1915. However, no further planned cuttings were mentioned in the rest of the plans. The standing tree volume increased in both stands 1 and 2 over the following years, as seen in the management plans from 1869, 1896 and 1915 (stand 1, 0-209 $\mathrm{m}^{3} \mathrm{ha}^{-1}$; stand 2, 0-141 $\mathrm{m}^{3} \mathrm{ha}^{-1}$ ). The volumes in both stands varied slightly during the 1920s and 1950s, and in 2014 the standing volumes in stands 1 and 2 were 7 and $14 \mathrm{~m}^{3} \mathrm{ha}^{-1}$, respectively, as a result of recent clear-cutting (Table 6). The forests in both stands were described as multi-aged in 1832. After the clear-cutting, the mean age increased slowly in both stands until 1957 (Table 6). The stands were clear-cut once more around the year 2000, and in 2014 the mean ages of stands 1 and 2 were 13 and 29, respectively. Norway spruce has been the predominant species in both stands throughout the study period, except in 1947, when Scots pine was the dominant tree species in stand 1, and 2014, when Scots pine and deciduous trees were the dominating tree species in stand 2 (Table 6). Birch has been present in both stands to a lesser extent and was more prevalent in stand 2.

Stands 3 and 4 were initially (in 1832) scheduled for clear-cutting, but this was never implemented. Instead, these stands were selectively logged during the period 1869-1896. The management plan from 1896 also included plans for the clear-cutting of both stand 3 and 4 , and further logging operations were planned for stand 4 according to the management plan from 1915. There is no information regarding the planned loggings for these stands from the rest of the plan periods. In 1832, the forests in both stand 3 and 4 had a standing tree volume of ca $180 \mathrm{~m}^{3} \mathrm{ha}^{-1}$ (Table 6). By 1869, the volumes had increased to 301 and $282 \mathrm{~m}^{3} \mathrm{ha}^{-1}$ in stands 3 and 4 , respectively. During the rest of the study period, the standing tree volume in stand 3 varied from a minimum of $75 \mathrm{~m}^{3} \mathrm{ha}^{-1}$ in 1947 to a maximum of $319 \mathrm{~m}^{3} \mathrm{ha}^{-1}$ in 2014. In stand 4, the volume also varied considerably, from a minimum of $0 \mathrm{~m}^{3} \mathrm{ha}^{-1}$ in 1915 to a maximum of $232 \mathrm{~m}^{3} \mathrm{ha}^{-1}$ in 2014 . The forests in both stand 3 and 4 were described as multi-aged in 1832 (Table 6). During the remainder of the study period, the forests in both stands were described as even-aged, although they had wide age ranges, gradually increasing until stand 4 had an age of zero in 1915 and stand 3 had an age of 5-15 years in 1947 as a result of clear-cutting. Norway spruce has been the predominant tree species in stand 3 throughout the study period, although there was some Scots pine and birch present (Table 6). Some of the plans also noted the presence of pedunculate oak, aspen and silver fir. Scots pine and Norway spruce were the predominant tree species in stand 4 throughout the study 


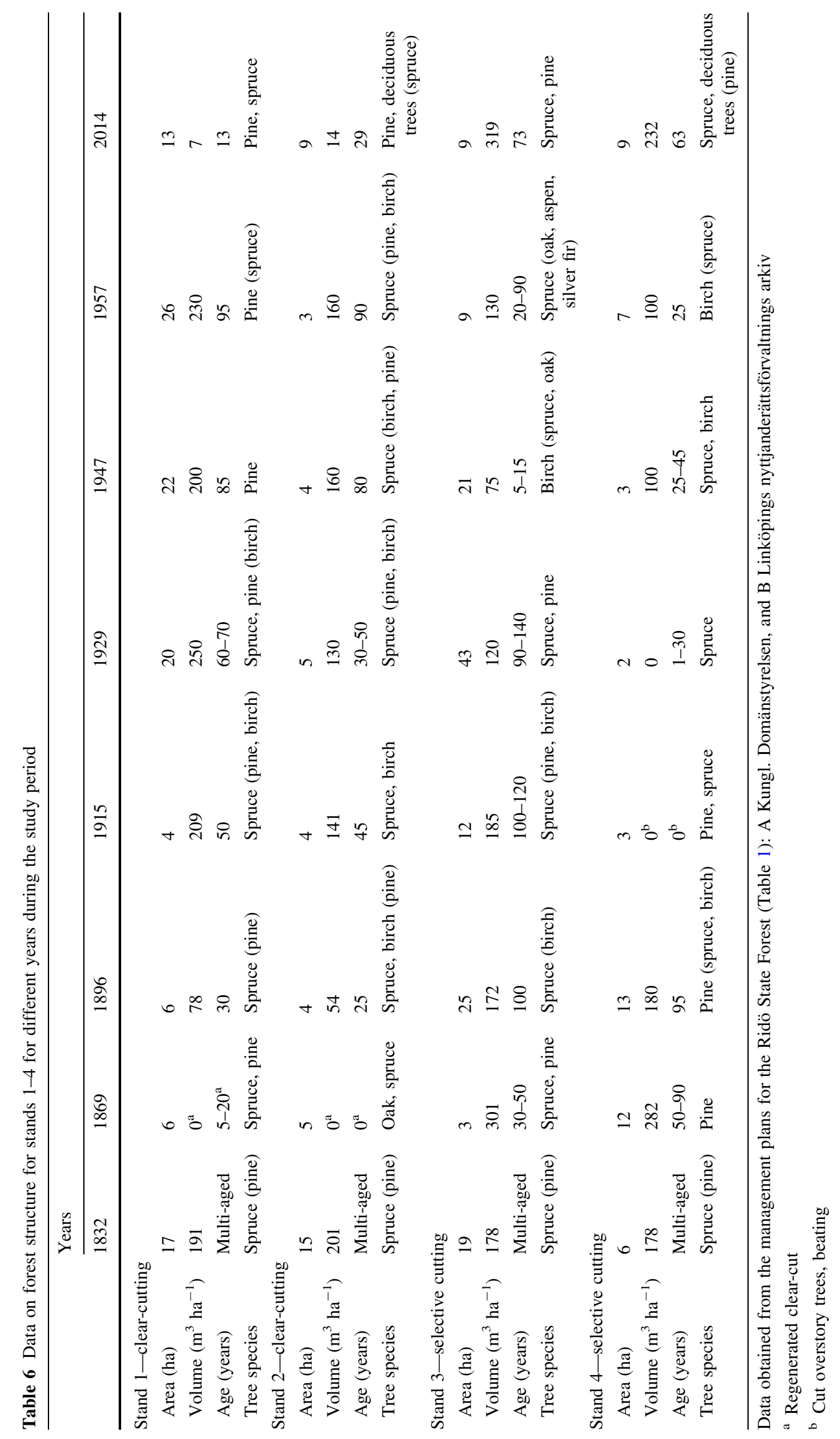


period, with birch and other deciduous trees, such as oak and aspen, also present, especially from 1947 onwards.

\section{Discussion}

Ridö State Forest is one of the few places in the Nordic countries where modern forestry has been applied according to an established forest management plan for an extensive period, and it also has a complete series of forest management plans and maps from the early 1800s until today. Thus, this is a unique study that contributes to the understanding of the emergence and development of modern forest management. It shows how detailed analysis of forest stands over long periods can inform us about changes in forestry and forest management, such as the shift back and forth between selective cutting and clearcutting, and their effects on forest structure. Such analyses put the forests' actual change in contrast to different forest management ideas.

The process which was initiated and practically applied at Ridö State Forest is clearly linked to the overall forest transition in Sweden. Forest transition is defined as the shift from net deforestation to net reforestation (Brunet et al. 2012), which takes place when areas that were previously utilized for agriculture are released for forestry (Mather and Needle 1998). This represents the situation on Ridön, as inhabitants initially made their living from agriculture and fishing, but as forestry gradually took this role the proportion of forest land increased. New forest was established, both by natural regeneration and planting, on abandoned land. The proportion of forest land increased significantly from 1896 to 1915 and at the end of the nineteenth century, the trend of decreasing standing volume also reversed, indicating that a major forest transition was occurring. The decrease in the area of forest land that can be seen between 1957 and 2014 is due to the fact that smaller surrounding islands were removed from the Ridö forest property. The sequence between the introduction of forest management and the moment of forest transition as well as the general duration of this important process corresponds between this case and other studies, in for example Denmark, where forest management was introduced during the mid-1700s and the forest transition took place during the early 1800s (Mather et al. 1998). At Ridön, there was also a time lag of approximately 70 years between the introduction of forest management and the moment of forest transition. Mather and Needle (1998) propose that when a country experiences a forest transition factors other than just agriculture, such as the perception of a crisis and the introduction of state policies for reforestation, are involved. This was also the case in Sweden, as there was widespread fear of forest depletion toward the end of the nineteenth century and, as a consequence, the first forestry act came into effect in the early 1900s (Nordström 1959).

\section{From "chaos" to order: the introduction of modern forest management}

The first forest management plan at Ridön had close connections to German ideas about forest management. According to the German forester Heinrich Cotta, a detailed forest map and a description of the forest were both crucial for systematic and organized forest management (Cotta 1865). This theoretical long-term model was based on tree age and should be able to turn the "chaotic" natural state of a forest into an "ordered" state. Clearcutting became common in Germany during the 1700s, and its introduction was largely justified by aspects of control (Nordström 1959). Clear-cutting represents merging of forestry and a scientific process, and by implementing this visionary idea, the foresters wanted to go from irregular exploitation of the forest to sustainable and predictable forest production (Juhlin Dannfelt 1959; Wiersum 1995; Farrell et al. 2000). The main goal of the first Ridö State Forest management plan was that, by the end of the plan, a new forest with higher yield would be established across the whole island. The conscious choice of tree species was one of the main characteristics of organized and long-term sustainable forestry throughout the Nordic countries (Sandmo 1951; Braathe 1980; Serup 2005). In this way, long-term sustainability was a main driving force for the foresters at Ridö State Forest, but at the time the concept only included timber production (cf. Wiersum 1995). Aspects such as long-term conservation of biodiversity and the functioning of ecosystems were included in this concept much later (Eriksson and Hammer 2006; Hahn and Knoke 2010). This is also clearly mirrored at Ridö State Forest where the initial focus on timber production successively has been widened to include other values such as wildlife and deciduous trees from the mid-1900s and onwards.

It was also clear that the foresters at Ridö State Forest had a very long-time perspective since the management plan from 1832 covered 120 years. Realistically the foresters could not know in advance how the forest would react to the applied management, especially since forest management was not tried before. However, at the time it was not unusual to make detailed long-term plans that would last for more than 100 years, since foresters believed that by organizing the forestry they gained complete control over the development of the forest (Ström 1839; Wahlgren 1914; Kardell 1988; Serup 2005). It is clear that the foresters had strong faith in their newly developed profession but they soon realized the difficulty of long-term 
planning since by 1869 , just 37 years after the first plan, they had set up a new plan with a much shorter period. This is consistent with the results of a study of Danish forestry by Serup (2005), which showed that plans initially included long-term perspectives, but were soon replaced with shorter planning horizons.

The forester Israel Adolf af Ström was a visionary and a forerunner in the introduction of forest management to Sweden. He set up the first forest management plan in Stockholm, Sweden and the proximity of Ridö State Forest to Stockholm probably influenced the decision to manage the forest according to modern principles so early, about 50 years before the general introduction of forest management in state forest (Arpi 1959). Furthermore, the fact that Ridön is an island and thereby a limited area, most likely contributed to the area being considered suitable for one of the first attempts at division of a forest for clearcutting. Ridön State Forest seems to have been a place for early forestry experimentation because this way to divide and manage the forest had not been tested previously and students from the Royal Forest Institute were allowed to set up the forest management plan on one occasion. This early forestry experimentation included a complete concept of German ideas that were tested practically on Swedish conditions. This led to cascading effects, such as stimulated development of forestry education, where af Ström became the link between school and forestry. The students then spread the new knowledge to other parts of Sweden. Clearly, this experimentation was of great importance as forest management and the clear-cutting system today, nearly 200 years later, still follow similar principles. This flexibility and willingness to experiment with management type and logging method is something that we can learn from today: the importance of evaluating the results of applied management and thereafter adapting forest management.

\section{Effects of forest management on forest structure}

Both the forest structure and spatial configuration of stands were affected by the introduction and development of forest management in Ridö State Forest from 1832 to 2014. Initially, the multi-aged mixed coniferous forests on Ridön were dominated by Norway spruce. The forest management plan from 1832 aimed to $\log$ the entire forest on the island and then replace it with a new and better growing forest and during the nineteenth century, the Scots pine was the preferred tree species. This was a common preference in central and northern Sweden during the nineteenth century, and the primary reason was that the Scots pine had a higher commercial value (Ericsson et al. 2000; Lundmark et al. 2013) and greater storm resistance with its deepreaching roots. However, our analysis of tree species composition at different points in time does not indicate a shift from spruce-dominated forests to pine-dominated forests during the study period for the island as a whole. Of the four stands that were studied in more detail, it is possible to distinguish a shift to pine in stand 4 , but this was only a temporary shift. The most likely scenario is that Scots pine was preferentially logged during the 1800 s, whereas both Scots pine and Norway spruce were logged during the 1900s, which led to an increase in deciduous trees. A photograph taken from the interior of one of the managed units in 1915 shows a few Scots pine trees, but the forest stand is clearly dominated by mature Norway spruce and a heavy regrowth of young spruce (Fig. 5).

The standing volume of the Ridö State Forest varied somewhat during the study period $\left(108-184 \mathrm{~m}^{3} \mathrm{ha}^{-1}\right.$; Table 5). However, on a local scale, the standing volume varied considerably, an effect of forest management and the applied logging methods. Interestingly, the standing volume in either stand 1 or 2 (managed only through clearcutting) never exceeded $200-250 \mathrm{~m}^{3} \mathrm{ha}^{-1}$, whereas stands 3 and 4 (managed through selective cutting during the $1800 \mathrm{~s}$ and clear-cutting during the 1900s) displayed standing volumes up to $280-319 \mathrm{~m}^{3} \mathrm{ha}^{-1}$ (Table 6). Furthermore, the annual yield of wood was higher during periods of selective cutting than during periods of clearcutting (Table 4), which could indicate that selective cutting generated higher standing volumes. The question of which logging method, clear-cutting or selective cutting, that generates higher standing volumes and wood yields is also relevant to today's society. In the Nordic countries (Cedergren 2008; Pukkala et al. 2014; Jacobsen et al. 2015), as well as in other parts of Europe (Bürgi 2015), future forest management has been extensively discussed, both from a management optimization and a biodiversity perspective. The advantages and disadvantages of continuous cover forestry are one of the focal points of these discussions. Unfortunately, the historical records from Ridö State Forest examined in this study do not enable the in-depth comparison of stands managed with only one logging method since stands 3 and 4 were eventually clear-cut, and because data on logged volumes for specific stands could not be extracted. However, future research using the approach presented in this study could add substantial knowledge to this discussion.

In the Nordic countries, the residual stands that resulted from selective cutting were generally considered as damaged and unproductive. Clear-cutting was used to "cleanup" the forest and to replace such stands with new forest that was more productive and fast growing (cf. Ebeling 1959; Juhlin Dannfelt 1959; Lie et al. 2011). In the Ridö State Forest, however, mature forest with dense stands was clear-cut. This demonstrates the foresters' expectations during the introduction of forest management: By replacing 


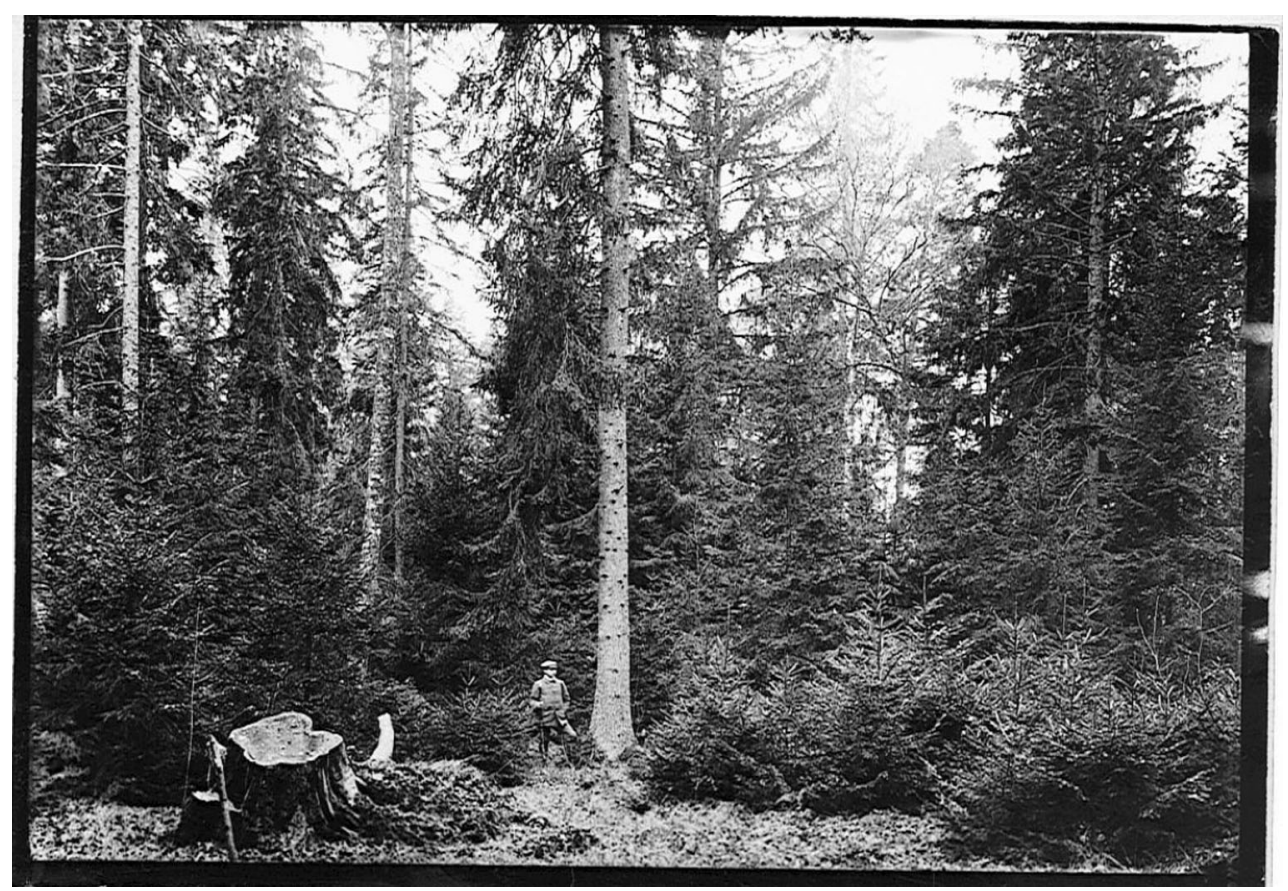

Fig. 5 Photograph showing the forest in management unit I:111 in 1914. Photograph taken by G. Lundberg. Source KD F3A (Table 1)

existing forest with new forest, they would be able to control the development of the forest and apply the appropriate management plan to the young forest, with the final goal being better growth that would produce a maximum yield. However, an underestimation of the growth and logging volume was noted when we compared the planned/estimated logging volume presented in the first management plan with the realized logging volume from the following 100-year period (Tables 3, 4). In this way, when forest management was first introduced, the management plans were static and the same model was applied to all forest land. Over time, foresters realized that certain tree species grew better at certain sites, indicating that the logging method should be adjusted to both site characteristics and tree species, i.e., forest management was becoming more site-adapted.

This change in management also changed the forest landscape at Ridön by affecting the spatial distribution of forest types and different age-classes forest. As seen in our analysis of the map series for the eastern part of the island, the four studied stands showed an overall trend of managed stands becoming smaller over the study period, i.e., an increased specialization of the division of the forest (Fig. 2a-h). On the one hand, the forests on Ridön were transformed from multi-aged mixed coniferous forests into even-aged coniferous forests with a large proportion of deciduous trees (Fig. 3a, b). On the other hand, the forests on Ridön initially had continuous areas of old mixed conifer forests, but today, the Ridö State Forest is more heterogeneous and divided into many small stands that represent the whole spectrum of age-classes, from clearcuts to mature forests with varying species composition. The change from multi-aged and multi-storied stands into homogeneous even-aged stands following organized forestry has been described previously by, for example, Östlund et al. (1997) and Axelsson et al. (2002). The overall trend during the last 150 years in northern and central Sweden has been a decrease in deciduous-rich forests (but see Hellberg et al. 2009). Also in southern Sweden, deciduous-rich forests have decreased (Lindbladh et al. 2014). However, the deciduous component of Ridö State Forest has increased during the last 100 years, and that is despite browsing and pre-commercial thinnings. This change in tree species composition is clearly an effect of the forest management, as birch has regenerated on clear-cuts and thinning operations have led to the removal of conifers. Clear-cutting usually increases the presence of pioneer tree species, such as birch and aspen trees (Zmihorski et al. 2010). Furthermore, the trend of smaller management units over time has been seen in other parts of Sweden and Norway as well (cf. Axelsson and Östlund 2001; Lie et al. 2011). Moreover, our study showed that not only did the management units become smaller, but their shapes also became more irregular. The straight north-tosouth lines on the first map (1832) can also be seen on the maps from 1869 to 1929 , but were from 1947 and onwards replaced by management units that have highly irregular shapes and sizes that vary from less than a hectare to several hectares. This change is in line with the emergence of new forestry theories at the beginning of the twentieth 
century, which, based on the knowledge gained about different habitat types, promoted site-adapted forest management (Ronge 1958).

The details in this study emphasize aspects that are important for the overall picture of past forest management, and such details that can be more difficult to distinguish in broader studies. The results provide a new picture of how the forest has been managed. First, that organized forest management has existed for so long, and second, that the introduction of clear-cutting occurred at the same time as the introduction of forest management. Today a large part of the area will become a nature reserve-despite or because of long-term forest management? Maybe we need to reassess on what basis we protect forests and how we manage high conservation value forests?

\section{Selective cutting versus clear-cutting}

The introduction of clear-cutting in the Nordic countries is often described as a transition from one logging method (selective cutting) to another (clear-cutting) (Sandmo 1951; Löfman and Kouki 2001; Kardell 2004; Aasetre and Bele 2009; Kuuluvainen et al. 2012). However, in the case of Ridö State Forests, clear-cutting was the logging method applied when forest management was introduced in 1832 . According to recent findings, Lundmark et al. (2013) suggest that both clear-cutting and selective cutting were regarded as rational methods of forest management long before selective cutting was phased out during the mid1900s. Selective cutting was first applied in Ridö State Forest during the second management plan (1869), and was later abandoned, as seen in our analyses of stands 3 and 4 (Table 6). An interesting question is why selective cutting was applied so early and then later abandoned in favor of clear-cutting? Our explanation is that the management plan from 1869 was drafted by students from the State Forest Institute, which makes it plausible that selective cutting was applied as part of an experiment. Even though the foresters soon reverted to clear-cutting, the 1869 plan initiated a discussion regarding the advantages and disadvantages of different logging methods. The discussion of clear-cutting versus selective cutting was ongoing then (Lundmark et al. 2013) and still is very much so today (Rämö and Tahvonen 2014). Early discussions mostly focused on storm resistance and regeneration. Clear-cutting was considered to create forests that were storm resistant while selective cutting was believed to increase the risk of storm damage. Those in favor of clear-cutting argued that this method provided satisfactory regeneration and was also able to control tree species composition, whereas foresters that were in favor of selective cutting argued that clear-cutting jeopardized regrowth (Lundmark et al. 2013).
Today, the issue of regeneration is still discussed, but the choice of logging method also takes into account ways to increase and maintain structural diversity (e.g., dead wood in different decay stages) and diversity of species and tree retention (Gustafsson et al. 2010; Simonsson et al. 2014).

\section{Conclusions}

Sweden contains some areas where forest management was introduced early and management plans were established from the very beginning. The scientific importance of the historical records that chronicle these management plans is twofold. First, the documents allow researchers to follow the development of a forest ecosystem under intensive management over a long period. Second, an analysis of the documents can reveal both the short-term and the longterm effects of specific management actions, such as clearcutting and selective cutting. Forest management has been conducted at Ridö State Forest for nearly 200 years, and different management methods, including both clear-cutting and selective cutting, have been applied during this period. Our analyses show that forestry has changed from the simple extraction of resources to sustainable forest management. During the study period, the forest was converted from a large continuous, heterogeneous forest to small homogenous stands with increased standing volume. Clear-cutting has in ideas-driven form been conducted in a controlled and structured way in Sweden during 200 years. In the case of Ridö State Forest, clear-cutting even preceded selective cutting, a finding that does not follow the general trend in the Nordic countries at the time. However, the debate on clear-cutting versus selective cutting (or continuous cover forestry) remains a hot topic even today. Foresters in the 1800s had a vision of creating forests for timber production, and they succeeded. Today, the Ridö State Forest is about to undergo another transformation, as most of Ridön will become a nature reserve in the near future. The goal is to create an uneven-aged forest with an increased deciduous component. We conclude that after 200 years of forest management for timber production, today's management for nature conservation will now aim toward creating a forest similar to the starting point in 1832. By analyzing spatially precise data on forest stands over long periods and in relation to contemporary silvicultural methods it is possible to discern the lasting impact of forest management and also to understand the drivers of the long-term changes in managed forest. This also allows for a more educated discussion on today's forest management methods as well as predictions about the future.

Acknowledgements This study was financially supported by Stiftelsen Nils och Dorthi Troëdssons Forskningsfond (Grant No. 771/11) 
and the research program Future Forests. Special thanks to Per Linder and John-Erik Hansson for all their help with archival material. We also thank Anna-Maria Rautio for helpful discussion and comments on an earlier version of this manuscript. Valuable advice about the map program, ArcGIS, was given by Mats Högström. We also wish to thank two anonymous reviewers for constructive comments. The English has been corrected by Sees-Editing, UK.

Open Access This article is distributed under the terms of the Creative Commons Attribution 4.0 International License (http://crea tivecommons.org/licenses/by/4.0/), which permits unrestricted use, distribution, and reproduction in any medium, provided you give appropriate credit to the original author(s) and the source, provide a link to the Creative Commons license, and indicate if changes were made.

\section{References}

Aasetre J, Bele B (2009) History of forestry in a central Norwegian boreal forest landscape: examples from Nordli, Nord-Trondelag. Nor J Geogr 63:233-245

Anon (2011) Inventering av kulturmiljöer i Södertälje kommunYtterenhörna och Överhörna socknar. Södertälje kommun (in Swedish)

Anon (2015) PM naturvärden Ridön. Länsstyrelsen i Stockholms län (in Swedish)

Arpi G (1951) Den svenska järnhanteringens träkolsförsörjning 1830-1950. Jernkontorets Bergshistoriska Skriftserie 14. Stockholm (in Swedish)

Arpi G (1959) Domänverkets allmänna utveckling. In: Arpi G (ed) Sveriges skogar under 100 år. En sammanfattande redogörelse över det svenska skogsbruket 1859-1959. Kungl. Domänstyrelsen, Stockholm, pp 529-544 (in Swedish)

Axelsson A-L, Östlund L (2001) Retrospective gap analysis in a Swedish boreal forest landscape using historical data. Forest Ecol Manag 147:109-122

Axelsson A-L, Östlund L, Hellberg E (2002) Changes in mixed deciduous forests of boreal Sweden 1866-1999 based on interpretation of historical records. Landsc Ecol 17:403-418

Björklund J (1984) From the Gulf of Bothnia to the White SeaSwedish direct investments in the sawmill industry of Tsarist Russia. Scand Econ Hist Rev 32:17-41

Boucher Y, Grondin P, Auger I (2014) Land use history (1840-2005) and physiography as determinants of southern boreal forests. Landsc Ecol 29:437-450

Braathe P (1980) Bakgrunnen for overgangen till bestandsskogbruket. Tidsskr Skogbruk 88:143-148 (in Norwegian)

Brunet J (2005) Skånes skogar-historia, mångfald och skydd [The forests of Skåne-History, diversity and conservation] (Skåne i utveckling 2005:12). Malmö, Länsstyrelsen i Skåne län (in Swedish)

Brunet J, Felton A, Lindbladh M (2012) From wooded pasture to timber production-changes in a European beech (Fagus sylvatica) forest landscape between 1840 and 2010. Scand J Forest Res 27:245-254

Brynte B (2002) CL Obbarius: en nydanare i Bergslagens skogar vid 1800-talets mitt. Skogs-och lantbrukshistoriska meddelanden 24. Stockholm: Kungl. Skogs-och lantbruksakademien (in Swedish)

Bürgi M (1999) A case study of forest change in the Swiss lowlands. Landsc Ecol 14:567-576

Bürgi M (2015) Close-to-nature forestry. In: Kirby K, Watkins C (eds) Europe's changing woods and forests: from wildwood to managed landscapes. CABI, Wallingford, pp 107-115

Bürgi M, Schuler A (2003) Driving forces of forest management-an analysis of regeneration practices in the forests of the Swiss
Central Plateau during the 19th and 20th century. Forest Ecol Manag 176:173-183

Cedergren J (2008) Kontinuitetsskogar och hyggesfritt skogsbruk. Skogsstyrelsens förlag, Jönköping (in Swedish)

Cotta H (1865) Heinrich Cotta's Anweisung zum Waldbau, Vierten edn. Arnoldische buchhandlung, Leipzig (in German)

Ebeling $\mathrm{F}$ (1959) Skogarna och deras vård i övre Norrland från och med 1930-talet. In: Arpi G (ed) Sveriges skogar under 100 år. En sammanfattande redogörelse över det svenska skogsbruket 1859-1959. Kungl. Domänstyrelsen, Stockholm, pp 413-443 (in Swedish)

Eliasson P (2002) Skog, makt och människor—en miljöhistoria om svensk skog 1800-1875. Skogs-och lantbrukshistoriska meddelanden 25, chapter 2, pp 47-66. Stockholm: Kungliga Skogs-och Lantbruksakademien (in Swedish)

Ericsson S, Östlund L, Axelsson A-L (2000) A forest of grazing and logging: deforestation history of a boreal landscape in central Sweden. New Forest 19:227-240

Eriksson S, Hammer M (2006) The challenge of combining timber production and biodiversity conservation for a long-term ecosystem functioning - a case study of Swedish boreal forestry. Forest Ecol Manag 237:208-217

Farrell EP, Führer E, Ryan D, Andersson F, Hüttl R, Piussi P (2000) European forest ecosystems; building the future on the legacy of the past. Forest Ecol Manag 132:5-20

Gustafsson L, Kouki J, Sverdrup-Thygeson A (2010) Tree retention as a conservation measure in clear-cut forests of northern Europe: a review of ecological consequences. Scand J Forest Res 25:295-308

Hahn WA, Knoke T (2010) Sustainable development and sustainable forestry: analogies, differences, and the role of flexibility. Eur J Forest Res 129:787-801

Hellberg E, Josefsson T, Östlund L (2009) The transformation of a Norway spruce dominated landscape since pre-industrial times in northern Sweden: the influence of modern forest management on forest structure. Silva Fenn 43:783-797

Hölzl R (2010) Historicizing sustainability: German scientific forestry in the eighteenth and nineteenth centuries. Sci Cult 19:431-460

Jacobsen JB, Jensen F, Thorsen BJ (2015) Forest value and optimal rotations in continuous cover forestry. IFRO Working Paper 2015/08. University of Copenhagen, Fredriksberg

Juhlin Dannfelt M (1959) Skogarna och deras vård i södra Sverige. In: Arpi G (ed) Sveriges skogar under 100 år. En sammanfattande redogörelse över det svenska skogsbruket 1859-1959. Kungl. Domänstyrelsen, Stockholm, pp 263-315 (in Swedish)

Kaplan JO, Krumhardt KM, Zimmermann N (2009) The prehistoric and preindustrial deforestation of Europe. Quat Sci Rev 28:3016-3034

Kardell L (1988) Skogsvårdens uppkomst. Kungl. Skogs- och lantbruksakademiens Tidskrift 127:163-181 (in Swedish)

Kardell L (2004) Svenskarna och skogen. Del 2: Från baggböleri till naturvård. Skogsstyrelsen, Jönköping (in Swedish)

Knuchel H (1953) Planning and control in the managed forest. Oliver \& Boyd, Edinburgh

Kuuluvainen T, Tahvonen O, Aakala T (2012) Even-aged and uneven-aged forest management in boreal Fennoscandia: a review. Ambio 41:720-737

Lie MH, Josefsson T, Storaunet KO, Ohlson M (2011) A refined view on the "Green lie": forest structure and composition succeeding early twentieth century selective logging in SE Norway. Scand J For Res 27:270-284

Lindbladh M, Axelsson A-L, Hultberg T, Brunet J, Felton A (2014) From broadleaves to spruce-the borealization of southern Sweden. Scand J Forest Res 29:686-696

Löfman S, Kouki J (2001) Fifty years of landscape transformation in managed forests of southern Finland. Scand J Forest Res 6:44-53 
Lundmark H, Josefsson T, Östlund L (2013) The history of clearcutting in northern Sweden-driving forces and myths in boreal silviculture. Forest Ecol Manag 307:112-122

Malmström C (1939) Hallands skogar under de senaste 300 åren. En översikt över deras utbredning och sammansättning enligt officiella dokuments vittnesbörd. Meddelanden från Statens skogsförsöksanstalt 31 (in Swedish)

Mather AS, Needle CL (1998) The forest transition: a theoretical basis. Area 30:117-124

Mather AS, Needle CL, Coull JR (1998) From resource crisis to sustainability: the forest transition in Denmark. Int J Sustain Dev World Ecol 5:182-193

Michelsen K-E (1999) Skogshistoria i Finland. In: Pettersson R, Tullgren E (eds) Skogshistorisk forskning i Europa och Nordamerika: vad är skogshistoria, hur har den skrivits och varför? Skogs- och lantbrukshistoriska meddelanden 22. Kungl. Skogs- och lantbruksakademien, Stockholm (in Swedish)

Noble IR, Dirzo R (1997) Forests as human-dominated ecosystems. Science 277:522-525

Nordström L (1959) Skogsskötselteorier och skogslagstiftning. In: Arpi G (ed) Sveriges skogar under 100 år. En sammanfattande redogörelse över det svenska skogsbruket 1859-1959. Kungl. Domänstyrelsen, Stockholm, pp 241-262 (in Swedish)

Östlund L (1999) Skogshistoria i Halland, Bergslagen och norra Norrland-jämförelser och tvärvetenskapliga perspektiv. In: Pettersson R, Tullgren E (eds) Skogshistorisk forskning i Europa och Nordamerika: vad är skogshistoria, hur har den skrivits och varför? Skogs- och lantbrukshistoriska meddelanden 22. Kungl. Skogs- och lantbruksakademien, Stockholm (in Swedish)

Östlund L, Zackrisson O, Axelsson A-L (1997) The history and transformation of a Scandinavian boreal forest landscape since the 19th century. Can J Forest Res 27:1198-1206

Pukkala T, Lähde E, Laiho O (2014) Stand management organization-the role of simplifications. Forest Ecosyst 1:1-11

Rämö J, Tahvonen O (2014) Economics of harvesting uneven-aged forest in Fennoscandia. Scand J Forest Res 29:777-792

Ronge EW (1958) Från Pehr Lagerhjelms skogar till våra dagars. Norrlands skogsvårdsförbunds tidskrift, pp 71-86 (in Swedish)

Sandmo JK (1951) Skogsbrukshistorie. Aschhoug \& Co, Oslo (in Norwegian)

Serup H (2004) Ordnet skovbruk i Danmark 1800-1950_planlægning og dyrkning på Silkeborg Statsskovdistrikt og Hvidkilde
Skovdistrikt. Dissertation, Royal Veterinary and Agricultural University, Denmark (in Danish)

Serup H (2005) Changing tree species composition in Danish private and state forestry 1800-1950. In: Internationale IUFRO Konferenz "Kulturerbe Wald". News of Forest History, vol III, No 36/37, pp 66-76

Simonsson P, Gustafsson L, Östlund L (2014) Retention forestry in Sweden: driving forces, debate and implementation 1968-2003. Scand J Forest Res 30(2):154-173

Ström IA (1822) Förslag till en förbättrad skogshushållning i Sverige, jemte utkast till dess systematiska verkställande. Kongl. Landtbruks-Akademien, Stockholm (in Swedish)

Ström IA (1839) Enkla reglor för skogars skötsel. Kongl. Landtbruksakademien, Stockholm (in Swedish)

von Berg E (1859) Berättelse om Finlands skogar. Finska Litteratursällskapets tryckeri, Helsingfors (in Swedish)

Wahlgren A (1914) Skogsskötsel: handledning vid uppdragande, vård och föryngring av skog. Norstedt, Stockholm (in Swedish)

Wahlgren A (1917) Historisk översikt av den högre skogsundervisningens utveckling i vårt land. Skogshögskolan, Stockholm (in Swedish)

Wahlgren A (1928) Israel Adolf af Ström och hans betydelse för svensk skogshushållning. In: Lagerberg T (ed) Festskrift utgiven med anledning av Skogshögskolans 100-årsjubileum 1828-1928. Centraltryckeriet, Stockholm, pp 1-31 (in Swedish)

Whitney GG (1994) From coastal wilderness to fruited plain. A history of environmental change in temperate North America 1500 to the present. Cambridge University Press, Cambridge

Wiersum KF (1995) 200 Years of sustainability in forestry: lessons from history. Environ Manag 19:321-329

Wieslander G (1936) Skogsbristen i Sverige under 1600- och 1700-talen. Sveriges skogsvårdsförbunds tidskrift 34:593-663 (in Swedish)

Williams M (2006) Deforesting the earth: from prehistory to global crisis: an abridgment. The University of Chicago Press, Chicago

Zmihorski M, Chylarecki P, Rejt L, Mazgajski TD (2010) The effects of forest patch size and ownership structure on tree stand characteristics in a highly deforested landscape of central Poland. Eur J Forest Res 129:393-400 